\title{
ANALISIS KEMAMPUAN KOMUNIKASI MATEMATIS SISWA SMP MELALUI PEMBELAJARAN BLENDED LEARNING DITINJAU DARI TIPE KEPRIBADIAN
}

\author{
Sry Nurhanifah ${ }^{1}$, Adang Effendi ${ }^{2}$, Ida Nuraida ${ }^{3}$ \\ 1,2,3 Program Studi Pendidikan Matematika, Universitas Galuh, Jl. R. E. Martadinata No.150, Ciamis, Indonesia \\ Email: srynurhnfh@gmail,com
}

\begin{abstract}
Mathematical communication skills are part of the learning objectives of mathematics that must be possessed by students. Mathematical communication ability can be known through the student's personality type. This study aims to determine the mathematical communication skills of junior high school students who have personality types in blended learning, there are two personality types, namely extrovert and introvert. This research uses descriptive qualitative method with triangulation technique. The subjects taken were class VIII students of SMP Negeri 2 Cikoneng for the 2020/2021 academic year by filling out a personality type questionnaire, taking a mathematical communication skill test in the form of 4 essay questions, and interviewing 6 students. The results of this study indicate that from mathematical communication skills based on extroverted personality types in blended learning, SE-1 subjects are able to fulfill 1 indicator, namely understanding and expressing mathematical ideas presented in writing or orally. While the introverted personality type, subjects SI-1, SI-2 and SI-3 were able to fulfill 1 indicator, namely in using mathematical representations (formulas, diagrams, tables, graphs, models) to express mathematical information.
\end{abstract}

Keywords: Mathematical Communication Ability, Blended Learning, Personality Type.

\begin{abstract}
ABSTRAK
Kemampuan komunikasi matematis merupakan bagian dari tujuan pembelajaran matematika yang harus dimiliki siswa. Kemampuan komunikasi matematis dapat diketahui melalui tipe kepribadian siswa. Penelitian ini bertujuan untuk mengetahui kemampuan komunikasi matematis siswa SMP yang memiliki tipe kepribadian dalam pembelajaran blended learning, terdapat dua tipe kepribadian yaitu extrovert dan introvert. Penelitian ini menggunakan metode kualitatif deskriptif dengan teknik triangulasi. Subjek yang diambil adalah siswa kelas VIII SMP Negeri 2 Cikoneng Tahun Pelajaran 2020/2021 dengan cara mengisi angket tipe kepribadian, melakukan tes kemampuan komunikasi matematis berupa 4 butir soal uraian, dan wawancara kepada 6 orang siswa. Hasil penelitian ini menunjukan bahwa dari kemampuan komunikasi matematis berdasarkan tipe kepribadian extrovert dalam pembelajaran blended learning, subjek SE-1 mampu memenuhi 1 indikator yaitu memahami dan mengungkapkan gagasan matematis yang disajikan dalam tulisan atau lisan. Sedangkan tipe kepribadian introvert, subjek SI-1, SI-2 dan SI-3 mampu memenuhi 1 indikator yaitu dalam menggunakan representasi matematika (rumus, diagram, table, grafik, model) untuk menyatakan informasi matematis.
\end{abstract}

Kata Kunci: Kemampuan Komunikasi Matematis, Blended Learning, Tipe Kepribadian.

Cara sitasi: Nurhanifah, S., Effendi, A., \& Nuraida, I. (2021). Analisis Kemampuan Komunikasi Matematis Siswa Smp melalui Pembelajaran Blended Learning ditinjau dari Tipe Kepribadian. J-KIP (Jurnal Keguruan dan IImu Pendidikan), 2(3), 111-118. 


\section{PENDAHULUAN}

Matematika adalah ilmu yang mempunyai peranan yang mendasar dalam perkembangan ilmu-ilmu lainnya yang berpengaruh langsung terhadap perkembangan teknologi (Maulana et al., 2021). Matematika merupakan salah satu bidang studi yang sangat penting dalam pendidikan, hal ini terlihat dari semua jenjang pendidikan mempelajari bidang studi matematika dengan jam pelajaran lebih banyak dibandingkan dengan pelajaran lainnya. Matematika sangat penting dipelajari karena dapat membentuk kepribadian siswa dan dapat mengembangkan kemampuan tertentu yang ada pada siswa. Salah satu dari tujuan dari pembelajaran matematika, yaitu mengkomunikasikan gagasan matematika dengan symbol, diagram atau media lain untuk memperjelas keadaan atau masalah. Dalam hal ini mengkomunikasikan gagasan matematika dengan symbol, diagram atau media lain untuk memperjelas keadaan atau masalah, menjadi salah satu tujuan dari pembelajaran matematika. Dalam hal ini, menunjukan bahwa pentingnya mempelajari matematika dalam mengkomunikasikan gagasan matmatika dengan symbol, diagram atau media lain untuk memperjelas keadaan atau masalah.

Kemampuan komunikasi matematika, NCTM (Susilo, 2018) mengemukakan bahwa kemampuan komunikasi matematika merupakan kemampuan siswa dalam menggunakan matematika sebagai alat komunikasi (bahasa matematika), dan kemampuan siswa dalam mengkomunikasikan matematika yang dipelajarinya sebagai isi pesan yang harus disampaikan. Kemampuan komunikasi yang baik membuat siswa dapat mengemukakan berbagai representasi yang beragam, sehingga siswa lebih mudah dalam menyelesaikan berbagai permasalahan dengan beragam alternatif. Pada kenyataannya, hal yang sering terjadi pada siswa dalam proses pembelajaran matematika adalah sebagian besar siswa masih bingung dalam memahami soal permasalah, sehingga akan mengalami kesulitan dalam menuangkan ke bentuk matematika, yang pada akhirnya mereka tidak dapat menentukan konsep atau rumus yang akan dipakai dalam menyelesaikan persoalan tersebut.

Upaya untuk meningkatkan kemampuan komunikasi matematis siswa adalah dengan menjadikan siswa aktif dalam proses pembelajaran di kelas, guru harus mampu memilih strategi yang sesuai dengan kondisi siswa yang diantaranya dengan menggunakan model pembelajaran berbasis blended learning. Salah satu bentuk interaksi siswa adalah saat siswa dengan guru atau siswa dengan siswa lainnya dapat mengungkapkan ide-ide matematis atau permasalah matematis baik itu pada saat pembelajran tatap muka langsung ataupun online. Menurut Astuti \& Novita (2019) menyatakan bahwa blended learning adalah suatu pembelajaran yang mengkombinasikan antara pembelajaran tatap muka, pembelajaran berbasis komputer, dan pembelajaran berbasis online (internet dan mobile learning) dengan prinsip dasar yaitu dapat mengoptimalkan komunikasi lisan yang ada pada pembelajran tatap muka dan komunikasi tertulis pada pembelajaran online sehingga diperoleh hasil belajar yang diharapkan.

Selain kemampuan komunikasi matematis siswa, karakteristik kepribadian siswa juga merupakan hal yang sangat penting. Maka sebelum proses pembelajaran dimulai diharapkan guru mengetahui karakteristik tipe kepribadian setiap siswa, sehingga guru dapat membedakan kemampuan komunikasi matematis siswa dari karakteristik tipe kepribadiannya. Yusuf \& Nurihsan (2013) mengungkapkan bahwa kepribadian diartikan sebagai seperangkat asumsi tentang kualitas tingkah laku manusia beserta definisi empirisnya. Jung berkesimpulan bahwa kepribadian seseorang adalah tipe dan karakter yang memiliki tanda dalam usaha penyesuaian diri dengan lingkungan yang berlaku pada komunitas seseorang. Menurut pandangannya terdapat 2 tipe kepribadian, yaitu tipe kepribadian ekstrivert dan tipe kepribadian introvert (Yusuf \& Nurihsan, 2013)

Kemampuan komunikasi siswa dengan tipe kepribadian ekstrovert biasanya terlihat dalam proses pembelajaran tatap muka, sedangkan untuk siswa dengan tipe kepribadian introvert lebih mempunyai rasa malu, kurang percaya diri dan tidak berani dalam menyampaikan ide yang 
dimilikinya, maka kemampuan komunikasi siswa tersebut kurang atau tidak lebih baik dari siswa ekstrovert yang memiliki kemampuan komunikasi lebih baik. Dalam hal ini, pembelajaran dengan menggunakan model blended learning akan meningkatkan kemampuan komunikasi siswa baik itu dalam lisan maupun tulisan yang memberikan kesempatan kepada siswa introvert dalam menyampaikan ide atau menyampaikan penyelesaian permasalahan matematika melalui tulisan begitupun dengan bentuk, simbol, grafik atau diagram.

\section{METODE PENELITIAN}

Metode penelitian yang digunakan dalam penelitian ini adalah pendekatan kualitatif deskriptif dengan teknik triangulasi. Penelitian deskriptif adalah penelitian yang berkaitan dengan pengumpulan data untuk memberikan gambaran atau penegasan suatu konsepp atau gejala, juga menjawab pertanyaan-pertanyaan sehubungan dengan suatu subjek penelitian pada saat ini, misalnya sikap ayau pendapat terhadap individu, organisasi, dan sebagainya. Teknik triangulasi adalah teknik pengumpulan data yang bersifat menggabungkan dari berbagai teknik pengumpulan data dan sumber data yang telah ada. Peneliti menggunakan observasi partisipatif, wawancara mendalam, dan dokumentasi untuk sumber data yang sam secara serempak. Menggunakan jenis penelitian ini dengan alasan, karena dapat menghasilkan kajian atas suatu fenomena yang bertolak pada data dengan memanfaarkan teori yang ada sebagai bahan penjelas.

Penelitian dilakukan secara luring dan daring ini, peneliti bertindak sebagai fasilitator. Instrument kunci dalam penelitian ini adalah objek yang diteliti yaitu siswa dengan menggunakan angket, tes tulis dan diperkuat dengan wawancara. Kemudian hasil yang diperoleh dari instrument tersebut disusun, diolah, dianalisis dan dideskripsikan untuk memperoleh gambaran tentang kemampuan komunikasi berdasarkan tipe kepribadian dalam pembelajaran blended learning, dengan dua tipe kepribadian yaitu extrovert dan introvert.

Objek dalam penelitian ini dilakukan pada siswa kelas VIII SMP Negeri 2 Cikoneng Tahun Pelajaran 2020/2021 yang tekah menerima materi Bangun Ruang yaitu Kubus dan Balok. Kemudian yang menjadi subjek penelitiannya dipilih dengan berdasarkan angket tipe kepribadian sebanyak 6 subjek dan kemudian 6 subjek ini diberikan tes kemampuan komunikasi matematis.

Prosedur penelitian yang dilakukan peneliti diantaranya, (1) tahap persiapan; (2) tahap pelaksanaan; (3) tahap analisis data; (4) tahap penarikan kesimpulan. Pada tahap persiapan penelitiaan, peneliti membuat instrument penelitian, diantaranya angket tipe kepribadian, instrument tes yaitu soal kemampuan komunikasi matematis berupa soal uraian dan pedoman wawancara. Setelah menyusun instrumen tes kemampuan komunikasi matematis berdasarkan indikator kemampuan komunikasi matematis, selanjutnya instrumen tes diujicobakan pada siswa kelas IX yang pernah mendapat pembelajaran mengenai materi tersebut. Kemudian peneliti melakukan analisis hasil uji coba tersebut dengan menggunakan uji validitas, reliabilitas, daya beda dan tingkat kesukaran denga tujuan untuk mengetahui kelajayakan instrument tes yang akan digunakan untuk penelitian. Berdasarkan hasil uji coba dipilih empat butir soal yang telah memenuhi kriteria soal yang bai untuk dijadikan sebagai alat ukur kemampuan komunikasi matematis.

Pada tahap pelaksanaan penelitian, kegiatan yang dilakukan secara online melalui goggle form dan whatapps video call. Google form non tes berupa angket, tes berupa soal dilakukan secara luring, dan whatapps video call untuk komunikasi lebih lanjut sebagai media wawancara.

Tahap analisis data penelitian ini Miles dan Huberman (1992), diantaranya (1) Reduksi Data; (2) Penyajian Data; (3) Menarik Kesimpulan.

\section{HASIL DAN PEMBAHASAN}

Data penelitian berdasarkan hasil angket tipe kepribadian, hasil tes kemampuan komunikasi matematis dan hasil wawancara yang telah dilakukan pada subjek penelitian yaitu 6 siswa kelas VIII 
SMP Negeri 2 Cikoneng. Berdasarkan hasil angket tipe kepribadian yang dilakukan secara online melalui google form, peneliti memilih 3 siswa dengan tipe kepribadian extrovert dan 3 siswa dengan tipe kepribadian introvert. Pemilihan 6 subjek ini, dilakukan berdasarkan beberapa pertimbangan yaitu, siswa dengan tipe kepribadian extrovert dan introvert diambil berdasarkan nilai tertinggi, sedang dan rendah. Adapun subjek penelitian yang terpilih adalah pada Tabel 1.

Tabel 1. Daftar Subjek Penelitian

\begin{tabular}{clc}
\hline No & Inisial Subjek & Tipe Kepribadian \\
\hline 1 & SE-1 & Siswa Ekstrovert \\
2 & SE-2 & Siswa Ekstrovert \\
3 & SE-3 & Siswa Ekstrovert \\
4 & SI-1 & Siswa Introvert \\
5 & SI-2 & Siswa Introvert \\
6 & SI-3 & Siswa Introvert \\
\hline
\end{tabular}

Berikut merupakan hasil analisis data pada tes soal uraian kemampuan komunikasi matematis, dengan kemampuan komunikasi matematis yaitu :

1) Memahami dan mengungkapkan gagasan matematis yang disajikan dalam tulisan atau lisan

2) Menggunakan pendekatan bahasa matematika (notasi, istilah dan lambang) untuk menyatkan informasi matematis

3) Menggunakan representasi matematika (rumus, diagram, table, grafik, model) untuk menyatakan informasi matematis

4) Mengubah dan menafsirkan informasi matematis dalam representasi matematika yang berbeda

Tabel 2. Data Hasil Tes Soal Uraian

\begin{tabular}{|c|c|c|c|c|}
\hline \multirow{2}{*}{$\begin{array}{c}\text { Tipe } \\
\text { Kepribadian }\end{array}$} & \multicolumn{4}{|c|}{ Indikator kemampuan komunikasi matematis } \\
\hline & 1 & 2 & 3 & 4 \\
\hline SE-1 & $\begin{array}{l}\text { Belum mampu } \\
\text { menyelesaikan } \\
\text { masalah dengan } \\
\text { benar dan } \\
\text { berdasarkan alasan } \\
\text { yang lengkap, dan } \\
\text { hanya mampu } \\
\text { menuliskan bahwa } \\
\text { rusuk sama panjang. }\end{array}$ & $\begin{array}{l}\text { Mampu menyelesaikan } \\
\text { masalah dengan benar } \\
\text { dan dapat menuliskan } \\
\text { tiga pasang rusuk yang } \\
\text { saling berpotongan } \\
\text { dengan bahasa } \\
\text { matematika serta mampu } \\
\text { mengilustrasikan mana } \\
\text { yang merupakan rusuk } \\
\text { berpotongan pada kubus. }\end{array}$ & $\begin{array}{l}\text { Mampu menyelesaikan } \\
\text { masalah dengan jawaban } \\
\text { yang benar dan dapat } \\
\text { menggunakan rumus } \\
\text { matematika, } \\
\text { belum namun } \\
\text { menuliskan informasi } \\
\text { matematis ke dalam } \\
\text { model matematika }\end{array}$ & $\begin{array}{lr}\text { Belum } & \text { mampu } \\
\text { mengubah informasi } \\
\text { matematis dalam } \\
\text { bentuk representasi } \\
\text { yang berbeda }\end{array}$ \\
\hline SE-2 & $\begin{array}{l}\text { Mampu } \\
\text { menyelesaikan } \\
\text { masalah dengan } \\
\text { benar namun kurang } \\
\text { tepat dan lengkap, } \\
\text { yaitu hanya } \\
\text { menyebutkan kubus } \\
\text { terdiri dari } 6 \text { sisi. }\end{array}$ & $\begin{array}{lr}\text { Hanya } & \text { mampu } \\
\text { menyebutkan } & \text { dua } \\
\text { pasanga } & \text { rusuk } \\
\text { berpotongan } & \text { dengan } \\
\text { benar dan satu } & \text { pasang } \\
\text { rusuk berpotongan yang } \\
\text { kurang tepat. }\end{array}$ & $\begin{array}{l}\text { Mampu menyelesaikan } \\
\text { masalah dengaan benar, } \\
\text { menggunakan rumus } \\
\text { matematika dan mampu } \\
\text { menuliskan informasi } \\
\text { matematis ke dalam } \\
\text { model matematika, } \\
\text { namun kurang mampu } \\
\text { dalam menuliskan } \\
\text { informasi dari } \\
\text { permasalahan tersebut. }\end{array}$ & $\begin{array}{l}\text { Belum mampu } \\
\text { mengubah informasi } \\
\text { matematis dalam } \\
\text { bentuk representasi } \\
\text { yang berbeda }\end{array}$ \\
\hline SE-3 & $\begin{array}{l}\text { Belum mampu } \\
\text { menyelessaikan } \\
\text { masalah dan hanya } \\
\text { mampu menyebutkan } \\
\text { panjang HE dan } A B \\
\text { itu sama. }\end{array}$ & $\begin{array}{l}\text { Mampu menyelesaikan } \\
\text { masalah tersebut dengan } \\
\text { menyebutkan dua pasang } \\
\text { rusuk berpotongan } \\
\text { dengan benar dan satu } \\
\text { pasang rusuk }\end{array}$ & $\begin{array}{l}\text { Dapat menggunakan } \\
\text { representasi matematika, } \\
\text { mampu menuliskan } \\
\text { model matematika, tetapi } \\
\text { jawaban yang ditulis } \\
\text { kurang tepat dan belum }\end{array}$ & $\begin{array}{lr}\text { Mampu } & \text { mengubah } \\
\text { informasi } & \text { matematis } \\
\text { dalam } & \text { bentuk } \\
\text { representasi } & \text { dan } \\
\text { mampu } & \text { mengubah } \\
\text { informasi } & \text { menjadi }\end{array}$ \\
\hline
\end{tabular}




\begin{tabular}{|c|c|c|c|c|}
\hline \multirow{2}{*}{$\begin{array}{c}\text { Tipe } \\
\text { Kepribadian }\end{array}$} & \multicolumn{4}{|c|}{ Indikator kemampuan komunikasi matematis } \\
\hline & 1 & 2 & 3 & 4 \\
\hline & & $\begin{array}{l}\text { berpotongan yang kurang } \\
\text { tepat }\end{array}$ & $\begin{array}{l}\text { mampu menuliskan } \\
\text { informasi matematis. }\end{array}$ & model matematika \\
\hline Sl-1 & $\begin{array}{l}\text { Mampu menulisakan } \\
\text { informasi matematis } \\
\text { dan } \quad \text { mampu } \\
\text { menuliskan } \\
\text { alasannya dengan } \\
\text { benar dan lengkap. }\end{array}$ & $\begin{array}{l}\text { Mampu menuliskan } \\
\text { jawaban dengan bahasa } \\
\text { matematika yaitu } \\
\text { menuliskan tiga pasang } \\
\text { rusuk berpotongan dan } \\
\text { mampu } \\
\text { mengilustrasikannya pada } \\
\text { kubus. }\end{array}$ & $\begin{array}{l}\text { Dapat menyelesaikan } \\
\text { masalah dan } \\
\text { menggunakan } \\
\text { representasi matematika } \\
\text { serta mampu menuliskan } \\
\text { infirmasi matematis ke } \\
\text { dalam model matematika. }\end{array}$ & $\begin{array}{lr}\text { Mampu } & \text { mengubah } \\
\text { informasi } & \text { matematis } \\
\text { dalam } & \text { bentuk } \\
\text { representasi } & \text { yang } \\
\text { berbeda } & \text { serta mampu } \\
\text { mengubah } & \text { informasi } \\
\text { menjadi } & \text { model } \\
\text { matematikar } & \end{array}$ \\
\hline $\mathrm{SI}-2$ & \begin{tabular}{lr}
\multicolumn{2}{l}{ Dapat menyelesaikan } \\
masalah & dengan \\
tepat dan & mampu \\
menuliskan & \\
alasannya & dengan \\
benar. &
\end{tabular} & $\begin{array}{l}\text { Mampu menuliskan } \\
\text { jawaban dengan benar } \\
\text { yaitu menuliskan tiga } \\
\text { pasang rusuk } \\
\text { berpotongan dan mampu } \\
\text { mengilustrasikannya pada } \\
\text { kubus. }\end{array}$ & $\begin{array}{l}\text { Mampu menyelesaikan } \\
\text { masalah dengan tepat, } \\
\text { dapat menggunakan } \\
\text { representasi matematika } \\
\text { dan mampu menuliskan } \\
\text { informasi matematis ke } \\
\text { dalam model matematika. }\end{array}$ & $\begin{array}{lr}\text { Mampu } & \text { mengubah } \\
\text { informasi } & \text { matematis } \\
\text { dalam } & \text { bentuk } \\
\text { representasi } & \text { yang } \\
\text { berbeda dan } & \text { mampu } \\
\text { mengubah } & \text { informasi } \\
\text { menjadi } & \text { model } \\
\text { matematika. } & \end{array}$ \\
\hline Sl-3 & $\begin{array}{l}\text { Mampu } \\
\text { menyelesaikan } \\
\text { masalah namun } \\
\text { jawaban yang ditulis } \\
\text { kurang tepat, dan } \\
\text { belum mampu } \\
\text { menuliskan } \\
\text { alasannya. }\end{array}$ & $\begin{array}{l}\text { Dapat menyelesaikan } \\
\text { masalah namun kurang } \\
\text { tepat, serta keliru dalam } \\
\text { menulis tetapi dapat } \\
\text { mengilustrasikannya ke } \\
\text { dalam kubus. }\end{array}$ & $\begin{array}{l}\text { Mampu menyelesasikan } \\
\text { masalah, menggunakan } \\
\text { representasi matematika } \\
\text { dan mampu menuliskan } \\
\text { informasi matematis ke } \\
\text { dalam matematis namun } \\
\text { masih terdapat kesalahan } \\
\text { dalam menghitung. }\end{array}$ & $\begin{array}{lr}\text { Mampu mengubah } \\
\text { informasi matematis } \\
\text { dalam bentuk } \\
\text { representasi yang } \\
\text { berbeda dan mampu } \\
\text { mengubah informasi } \\
\text { menjadi model } \\
\text { matematika, namun } \\
\text { penyelesaiannya } \\
\text { kurang tepat }\end{array}$ \\
\hline
\end{tabular}

Berdasarkan hasil penelitian dan analisis data yang telah dilakukan oleh peneliti, diperoleh pembahasan mengenai deskripsi kemampuan komunikasi matematis siswa ditinjau dari tipe kepribadian pada siswa SMP Negeri 2 Cikoneng tahun pelajaran 2020/2021 dalam mengerjakan soal tes yang memuat indikator kemampuan komunikasi matematis adalah sebagai berikut :

\section{A. Kemampuan Komunikasi Matematis Siswa dengan Tipe Kepribadian Extrovert dalam pembelajaran Blended Learning}

Pada pnelitian ini, subjek untuk kemampuan komunikasi matematis dengan tipe kepribadian ekstrovert yang telah melalui pembelajaran bended learning adalah SE-1, SE-2 dan SE-3. Hasil analisis yang telah dilakukan dari hasil tes kemampuan komunikasi dan hasil wawancara dari subjek SE-1 dan SE-2 hanya mampu memenuhi dalam mengungkapkan gagasan matematis secara lisan namun SE-1 dan SE-2 belum mampu mengungkapkan gagasannya dalam tulisan. Sedangkan SE-3 belum mampu memenuhi indikator kemampuan komunikasi matematis dalam mengungkapkan gagasan matematis secara tulisan maupun lisan.

Pada indikator 2, hanya subjek SE-1 yang mampu memenuhi indikator kemampuan komunikasi matematis yaitu dalam menggunakan pendekatan bahasa matematia (notasi, istilah dan lambang) untuk menyatakan informasi matematis. Sedangkan SE-2 dan SE-3 belum mampu memenuhi indikator 2.

Pada indikator 3 yaitu, menggunakan representasi matematika (rumus, diagram, table, grafik, model) untuk menyatakan informasi matematis, kemampuan komunikasi matematis subjek SE-1, SE-2 dan SE-3 hanya mampu memenuhi indikator dalam menggunakan 
representasi matematika untuk menyatakan informasi matematis secara lisan tidak melalui tulisan.

Pada indikator 4, semua subjek yaitu SE-1, SE-2, dan SE-3 belum mampu memenuhi indikator kemampuan komunikasi matematis yaitu mengubah dan menafsirkan informasi matematis dalam representasi matematika yang berbeda dalam tulisan atau lisan. Subjek SE-1, SE-2, dan SE-3 belum mampu memahami permasalahan dalam soal tersebut, sehingga subjek SE-1, SE-2 dan SE-3 tidak dapat mengubah dan menafsirkan informasi matematis dalam representasi matematika yang berebda dalam tulisan maupun lisan. Siswa ekstrovert sulit memahami soal matematika, sehingga kemampuan komunikasi matematis siswa ekstrovert belum mampu mengubah dan menafsirkan informasi matematis dalam representasi matematika yang berbeda.

B. Kemampuan Komunikasi Matematis Siswa dengan Tipe Kepribadian Introvert dalam pembelajaran Blended Learning

Pada pnelitian ini, subjek untuk kemampuan komunikasi matematis dengan tipe kepribadian introvert yang telah melalui pembelajaran bended learning adalah SI-1, SI-2 dan SI-3. Hasil analisis yang telah dilakukan dari hasil tes kemampuan komunikasi dan hasil wawancara dari subjek hanya SI-1 yang mampu memenuhi dalam mengungkapkan gagasan matematis secara tulisan atau lisan. Namun SI-2 dan SI-3 hanya mampu mengungkapkan gagasannya dalam tulisan.

Pada indikator 2, subjek yang memenuhi indikator kemampuan komunikasi matematis dalam menggunakan pendekatan bahasa matematika (notasi, istilah dan lambang) untuk menyatakan informasi matematis adalah SI-1 dan SI-2. Sedangkan SI-3 belum mampu memenuhi indikator kemampuan komunikasi matematis 3.

Pada indikator 3, subjek SI-1, SI-2 dan SI-3 mampu memenuhi kemampuan komunikasi matematis yaitu dalam menggunakan representasi matematika (rumus, diagram, table, grafik, model) untuk menyatakan informasi matematis.

Pada indikator 4, subjek SI-1, SI-2 dan SI-3 mampu memenuhi indikator 4 yaitu mengubah dan menafsirkan informasi matematis dalam representasi matematika yang berbeda melalui tulisan namun belum mampu mengubah atau menafsirkan informasi matematis dalam representasi matematika yang berbeda secara lisan.

\section{KESIMPULAN}

Berdasarkan analisis data hasil penelitian diperoleh kesimpulan bahwa kemampuan komunikasi matematis berdasarkan dari tipe kepribadian extrovert dalam pembelajaran blended learning yaitu : (1) belum mampu memahami dan mengungkapkan gagasan matematis yang disajikan dalam tulisan, (2) mampu mengungkapkan pendekatan bahasa matematika untuk menyatakan informasi matematis, (3) belum mampu menggunakan representasi matematika untuk menyatakan informasi matematis dalam tulisan, (4) belum mampu mengubah dan menafsirkan informasi matematis dalam representasi matematika yang berbeda dalam tulisan atau lisan.

Kemampuan komunikasi matematis berdasarkan dari tipe kepribadian introvert dalam pembelajaran blended learning yaitu : (1) belum mampu memahami dan mengungkapkan gagasan matematis yang disajikan secara lisan, (2) mampu mengungkapkan pendekatan bahasa matematika untuk menyatakan informasi matematis, (3) mampu menggunakan representasi matematika untuk menyatakan informasi matematis dalam tulisan atau lisan, (4) belum mampu mengubah dan menafsirkan informasi matematis dalam representasi matematika yang berbeda secara lisan. 


\section{REKOMENDASI}

Hasil penelitian ini memberikan informasi mengenai gambaran kemampuan komunikasi matematis yang dimiliki oleh siswa dengan tipe kepribadian extrovert dan introvert dalam pembelajaran blended learning.

1) Penelitian ini dilaksanakan secara luring dengan waktu yang terbatas dikarenakan dalam kondisi Pemberlakuan Pembatasan Kegiatan Masyarakat (PPKM), maka dari itu untuk peneliti selanjutnya sebaiknya dapat mempersiapkan penelitiannya jika sewaktu-waktu masih dalam kondisi seperti ini.

2) Rekomendasi bagi guru mata pelajaran matematika dapat meningkatkan indikator kemampuan komunikasi matematis yaitu dalam mengubah dan menafsirkan informasi matematis dalam representasi matematika yang berbeda baik dalam tulisan maupun lisan.

3) Bagi peneliti lain, hasil penelitian ini dapat digunakan sebagai bahan kajian dan pengembangan untuk melakukan penelitian selanjutnya terkait kemampuan komunikasi matematis siswa dalam pembelajaran blended learning yang ditinjau dari tipe kepribadian extrovert dan introvert.

\section{UCAPAN TERIMAKASIH}

Penulis mengucapkan terima kasih kepada Allah SWT yang telah memberikan rahmat dan hidayah-Nya sehingga penulis dapat menyelesaikan artikel ini. Tak lupa saya ucapkan terimakasih kepada Program Studi Pendidikan Matematika Fakultas Keguruan dan IImu Pendidikan Universitas Galuh yang telah memfasilitasi penulis melaksanakan kegiatan oenelitian; Bapak Dr. Adang Effensi, S,T., M.Pd., dan Ibu Dr. Ida Nuraida, M.Pd., yang telah berkontribusi dan membimbing penulis dalam melaksanakan penelitian, sehingga penelitian berjalan lancar dan tepat waktu; dan kepada kepala sekolah serta guru mata pelajaran matematika di SMP Negeri 2 Cikoneng yang telah mengizinkan peneliti melaksanakan penelitian.

\section{DAFTAR PUSTAKA}

Astuti, D. A., \& Novita, D. (2019). Blended LearningTerhadap Kemampuan Komunikasi Matematis. Prosiding Sendika, 5(1).

Miles, B. M \& Huberman M. (1992). Analisis Data Kualitatif Buku Sumber Tentang Metode-metode Baru. Jakarta: UIP.

Maulana., Zamnah, L.N., \& Amam, A. (2021). Pengembangan bahan ajar berbasis aplikasi geogebra Pada materi bangun ruang sisi datar berdasarkan kemampuan pemahaman matematis siswa. J-KIP (Jurnal Keguruan dan IImu Pendidikan), 2 (2), 1-8

Susilo, J. (2018). Analisis Metakognisi Terhadap Komunikasi Matematika dalam Blended Learning Menggunakan Google Classroom. Doctoral dissertation, Universitas Negeri Semarang.

Yusuf, S. \& Nurihsan, A. J. (2013). Teori Kepribadian. PT Remaja Rosdakarya, Bandung. 
